\title{
A walk down the Cap de Creus canyon, Northwestern Mediterranean Sea: Recent processes inferred from morphology and sediment bedforms
}

\author{
Lastras, G. ${ }^{1,2}$, Canals, M. ${ }^{1,{ }^{*}}$, Urgeles, R. $^{1}$, Amblas, D. ${ }^{1}$, Ivanov, M. ${ }^{3}$, \\ Droz, L. ${ }^{4}$, Dennielou, B. ${ }^{5}$, Fabrés, J. ${ }^{1,6}$, Schoolmeester, T. ${ }^{1,7}$, \\ Akhmetzhanov, A. ${ }^{2}$, D. Orange ${ }^{8,9}$, A. García-García ${ }^{8,9}$
}

\author{
${ }^{1}$ GRC Geociències Marines, Universitat de Barcelona, E-08028, Spain \\ ${ }^{2}$ National Oceanography Centre, Southampton, SO14-3ZH, United Kingdom \\ ${ }^{3}$ UNESCO Centre of Marine Geology and Geophysics, Moscow State University, Moscow, Russia \\ ${ }^{4}$ Université de Bretagne Occidentale-CNRS, Plouzané, F-29280, France \\ ${ }^{5}$ Département des Géosciences Marines, IFREMER, BP70, Plouzané, F-29280, France \\ ${ }^{6}$ current address: State University of New York, Stony Brook, New York 11794-5000, USA \\ ${ }^{7}$ current address: UNEP/GRID-Arendal, Teaterplassen 3, N-4836 Arendal, Norway \\ ${ }^{8}$ Department of Earth Sciences, UCSC, Santa Cruz, CA 95064, USA \\ ${ }^{9}$ AOA Geophysics Inc., 7532 Sandholdt Rd., Suite 6, Moss Landing, CA 94039, USA
}

*: Corresponding author : Canals M., email address : miquelcanals@ub.edu

\begin{abstract}
:
The Cap de Creus canyon, northwestern Mediterranean Sea, belongs to a complex network of submarine canyons cutting the western Gulf of Lion continental shelf and opening into the larger Sète canyon. Swath bathymetry data, MAK-1M deep-towed side-scan sonar imagery and $5 \mathrm{kHz}$ high resolution seismic reflection profiles show striking morphologies in the Cap de Creus canyon floor and walls. As a consequence of the canyon head and the upper reach severe incision, the continental shelf dramatically narrows in front of the Creus Cape promontory. The upper canyon has a flatbottomed thalweg incised in a mega-scale sediment furrow field displaying hyperbolic seismic facies. The tens of kilometres long linear furrows extend also over the middle canyon down to $1400 \mathrm{~m}$ of water depth. The furrows on either side of the canyon are not parallel but oblique and display varying degrees of excavation. Mid-channel sediment bars are locally present in the thalweg, which is made of sandy lag deposits, as revealed by its acoustic response and verified by sediment samples. The middle canyon is linear and steep, with an up to $700 \mathrm{~m}$ high southern wall, contrasting with the sinuous, smooth lower canyon, which is controlled by flowage of the underlying Messinian evaporites. Large sections of the canyon are affected by sediment instability processes. The lower Cap de Creus canyon hangs up to $260 \mathrm{~m}$ over its distalmost reach and the Sète canyon through a narrow, less than $1 \mathrm{~km}$ wide, gorge. Numerous scours up to $10 \mathrm{~m}$ deep suggesting bed load transport occupy the lower Sète canyon immediately downstream of the Cap de Creus canyon mouth.
\end{abstract}

The data set provides the first complete very-high resolution imaging of a submarine canyon from its upper part down to its distalmost reach. The observations evidence a wide set of erosion, transport and deposition processes along the Cap de Creus canyon, including sediment entrapment at the canyon head, furrow-generating dense water cascading through the southern wall, along-channel currents strong enough to excavate specific sections of the channel floor and bed load sediment transport as demonstrated by the presence of mega-ripples, crescent scours and grooves in the lower canyon.

Keywords: submarine canyon; side scan sonar; swath bathymetry; bedform; Gulf of Lion 


\section{Introduction}

Submarine canyons, together with gullies and other types of seafloor valleys, are present in most of the modern continental margins around the world, both active and passive (Daly, 1936; Shepard and Dill, 1966; Normark and Piper, 1969; Shepard, 1981; Farre et al., 1983; Hagen et al., 1994). Their location and morphology are controlled by multiple factors, including structural fabric, regional tectonism, sea-level variations and sediment supply (Laursen and Normark, 2002; Soh and Tokuyama, 2002). Although many are built in and confined to the upper slope, some deeply indent the continental shelf and extend beyond the lower slope, intersecting the along-shore sediment transport systems and significantly favouring the dispersal of terrigenous sediment by down-canyon gravity-driven sediment flows to the deep basins (Shepard and Dill, 1966; May et al., 1983; Carson et al., 1986; Gardner, 1989; Pratson and Coakley, 1996; Mullenbach et al., 2004). The canyons reaching greater depths often either end at delta-like submarine fans (Bellaiche et al., 1983; Droz et al., 1993; Babonneau et al., 2002) or merge into deep ocean channel systems (Lewis and Barnes, 1999; Canals et al., 2000).

This direct connection between the sediment sources along the continental shelf and the deep sea occurs specially during sea-level low-stands, when down-canyon gravity-driven sediment flows are the main mechanism of sediment transfer to the deep sea (Nelson et al., 1978; Cirac et al., 200 I; Popescu et al., 2004). On the contrary, entrapment of sediment on deltas and broad shelves reduces sediment transport through submarine canyons during high-stands (Shanmugam et al., 1985), and hemipelagic sedimentation seems to be the primary source of sediment (Durrieu de Madron, 1994).

Nevertheless, at a few places, canyons have retained their coastal supply during the present highstand, in particular those located off major rivers (Droz et al., 1996; Babonneau et al., 2002) or on narrow margins (Savoye et al., 1993). These canyons seem to be the most frequently active today (Droz et al, 1996; Lewis and Barnes, 1999), although canyons need not necessarily to be linked to specific fluvial sources to be active (Pratson and Coakley, 1996; Mullenbach et al., 2004). Apart from sediment supply, submarine erosion plays a major role in canyon development (Twichell and Roberts, 1982; Popescu et al., 2004; Baztan et al., 2005) as well as mass wasting of the canyon walls and retrogressive sediment failure in the canyon head (Pratson and Coakley, 1996; Sultan et al., 2007).

This study deals mainly with the geomorphological aspects of the Cap de Creus canyon in the Gulf of Lion (Fig. I), but also focuses on the implications of the morphologies observed in terms of canyon development, evolution and dynamics. Based on high-resolution side-scan sonar data obtained along the axis of the Cap de Creus canyon, from the shelf-indenting head to its furthest reaches after joining the Sète canyon, combined with swath bathymetry data collected over the years, we will describe the most recent history of the Cap de Creus canyon and the sedimentary processes, both constructive and destructive. 


\section{Geological setting}

The Gulf of Lion, where the Cap de Creus canyon is located, is the prograding passive margin limiting the deep Provençal basin to the north. Its genesis is linked to the convergent relative movements between the African and European continental plates that led to the successive opening of the western Mediterranean sub-basins from west to east during the last $30 \mathrm{Myr}$, and which still takes place in the Valencia trough (Le Pichon et al., I97I; Maillard and Mauffret, 1999). The Provençal basin opened during the upper Oligocene and lower Miocene coevally with a counter-clockwise rotation of the Corsican-Sardinian blocks (Gueguen et al., 1998). Widespread evaporitic deposition took place during the Messinian salinity crisis (Hsü, 1977). Evaporite thickness locally reaches up to $2 \mathrm{~km}$ (Réhault et al., 1984). Subsequent salt tectonics formed salt domes and diapirs in the deep basin and salt-related listric faults in the lower slope affecting post-Messinian marine sequences (Burollet and Byramjee, 1974; Canals, 1985; dos Reis et al., 2005).

Most of the sediment reaching the micro-tidal Gulf of Lion comes from the Rhône river, with a supply of around eight millions tons of sediment per year, although it was much higher in the past (Pont et al., 2002). The Têt and the Aude, among other Pyrenean and Languedocian rivers, have a torrential regime and supply nearly four millions tons of sediment per year. This sediment is redistributed by eastward and southward currents induced by western winds on the shelf, and by the Northern Current on the slope, a geostrophic current following the continental slope south-westwards (Millot, 1990).

Bathymetric and seismic data from the whole Gulf of Lion (Berné et al., 1999, 2004; Berné and Gorini, 2005) show three main physiographic provinces: (a) a $>70 \mathrm{~km}$ wide continental shelf $\left(0.1^{\circ}\right)$ with a depositional pattern recording at least five glacioeustatic cycles (Rabineau et al., 2005 ) and where, at depths ranging from 90 to $120 \mathrm{~m}$, relict coarse-grained coastal deposits from the last major sea-level lowstand have been reported (Tesson et al., 1998; Rabineau et al., $2005)$; (b) a rough continental slope $\left(1.5^{\circ}\right)$ dissected by a complex network of numerous shelfindented submarine canyons, from the Cassidagne canyon offshore Marseille, through the Grand-Rhône, Petit-Rhône, Marti and Sète canyons, to the Pyrenean canyons (Berné et al., 1999), which funnel an enormous volume of siliciclastic sediment mainly in form of turbidity currents down to a (c) complex continental rise $\left(0.9^{\circ}\right)$. The Cap de Creus canyon is the southwesternmost submarine canyon in the Gulf of Lion and one of the Pyrenean canyons together with the Lacaze-Duthiers, the Prudot and the Aude canyons (Fig. I). It is generally considered the border between the Gulf of Lion and the Catalan margin.

Recent studies made in the framework of the EuroSTRATAFORM project have pointed to the importance of dense shelf water cascading in the Cap de Creus canyon (Canals et al., 2006; Palanques et al., 2006; Gaudin et al., 2006). Dense water forms on the shelf by persistent, strong, cold northerly winds and low river discharge (Palanques et al., 2006), and then sinks, overflowing the shelf edge. During cascading events, current speed reaches up to I $\mathrm{m} \mathrm{s}^{-1}$ enhancing along-canyon sediment transport, even of coarse particles, to the deep sea (Canals et al., 2006). Channel erosion due to hyperpycnal, river-connected turbidity currents is the most probable mechanism for the formation of modern narrow inner valley (axial) incisions in most of the western canyons (Berné et al., 1999; Baztan et al., 2005).

These two current types result in the deposition of sediment bodies in the continental rise such as the Rhône deep-sea fan, which covers parts of the central basin and is fed by the PetitRhône canyon and its distributaries (Droz and Bellaiche, 1985), the Marseille and Grand-Rhône sedimentary ridges to the east, and the Pyrenean canyon deep sedimentary complex (PDSC) (Alonso et al., 199I), whereas other seismically transparent units, such as the Western debris flow, have been attributed to large-scale mass-wasting events (Méar, 1984). The PDSC is a Middle to Upper Pleistocene, 800-1000 ms two-way travel time thick, sedimentary ridge 
constituting the right-hand flank of the Cap de Creus canyon lower reach (dos Reis et al., 2004; Jallet and Giresse, 2005), successively identified by Got (1973), Canals (1985), Alonso et al. (199I) and Berné et al. (1999), and described as a submarine fan (Got and Stanley, 1975; Jallet and Giresse, 2005) fed by the Pyrenean and Sète canyons (dos Reis et al., 2004). These canyons were then straight, sub-parallel features running downslope, and their present-day confluence was established recently (Canals, 1985; dos Reis et al., 2005). Salt-tectonics and salt-related structures have had direct implications on the sedimentary architecture of this depositional system, both by creating bathymetric relief and accommodation space for deposition (dos Reis et al., 2005).

\section{Materials and methods}

This study is mainly based on deep-towed side-scan sonar and swath bathymetry data. Sidescan sonar data (Fig. I) was obtained onboard R/V Professor Logachev in August 2004, using a MAK-IM deep-towed platform. The MAK-IM consists of a $30 \mathrm{kHz}$ side-scan sonar that yields a total swath range of up to $2 \mathrm{~km}$ from a mean altitude of $100 \mathrm{~m}$ above the seafloor at a mean speed of 2.5 knots, with a variable resolution of about 7 to $1 \mathrm{~m}$ across track and along track, and a high-resolution acoustic profiler operating at $5 \mathrm{kHz}$. The system was first operated upcanyon up to $1800 \mathrm{~m}$ water depth, hoisted, and later deployed at ca. $600 \mathrm{~m}$ water depth to be towed in a down-canyon direction in order to ease maneuvering. Side-scan sonar does not give direct quantitative information about the seafloor topography but measures backscatter, a qualitative value mainly depending on seafloor morphology and dip but also on seabed properties. Sonographs are presented in inverse grey-scale, that is to say, insonified areas are dark grey and black, whereas shadows are represented in white.

Swath bathymetry dataset was acquired onboard the B.I.O. Hespérides in August 2002 and onboard the $M / V$ Geo Prospector in June 2004 using different models of Simrad multibeam echosounders, EM-I 2 in deep and EM-3000 in shallow waters, but also EM-300 in the Cap de Creus canyon head area. The dataset was complemented with a compilation of a multibeamderived data (Fig. I) from several cruises that took place between 1995 and 2002 onboard R/V L'Atalante, R/V L'Europe and R/V Le Suroit. Data were analyzed and displayed with the Generic Mapping Tools (Wessel and Smith, 1998). Quality of data allowed preparing bathymetric grids with grid spacings varying from $4 \mathrm{~m}$ for the canyon head and upper canyon, $50 \mathrm{~m}$ for the middle and part of the lower canyon, and $200 \mathrm{~m}$ for distalmost reach.

\section{Results: Morphology of the Cap de Creus canyon}

The $96.1 \mathrm{~km}$ long Cap de Creus canyon dissects the continental slope and rise in a general west-east direction until it joins the Sète canyon at $42^{\circ} 15^{\prime} \mathrm{N}$ and $4^{\circ} 20^{\prime} \mathrm{E}$ at ca. $2100 \mathrm{~m}$ water depth (Fig. I). On a straight line, the canyon head is $86.3 \mathrm{~km}$ northwest of this merging point, thus yielding a sinuosity index of I.II ( 1.16 for the canyon thalweg, as calculated by Baztan et al., 2005).

The Cap de Creus canyon can be subdivided in four sectors: ( $I$ ) the canyon head, from the shelf break down to $400 \mathrm{~m}$, (2) the upper canyon, between 400 and $1000 \mathrm{~m}$, (3) the middle canyon, down to $1600 \mathrm{~m}$, and (4) the lower canyon down to $2100 \mathrm{~m}$ (Figs. IB and 2). Criteria for this subdivision include mean slope gradient, orientation, canyon width and other morphological criteria, as well as the geological processes identified in each sector. These morphological characteristics are explained in the following paragraphs.

\section{I. Canyon head and upper canyon}


The Cap de Creus canyon head is located north of the Creus Cape (Cap de Creus, in Catalan) at $42^{\circ} 25^{\prime} 30^{\prime \prime} \mathrm{N}$ and $3^{\circ} 18^{\prime} \mathrm{E}$, at scarcely six nautical miles $(\sim \mathrm{I} \mathrm{km})$ east of the border between France and Spain (Fig. 3). Both the canyon head and the upper reach deeply incise the continental shelf, producing a pronounced narrowing of the shelf to $4 \mathrm{~km}$ just in front of the Creus Cape promontory (Fig. 3). The canyon head starts at 125 meters water depth. It is 5.5 $\mathrm{km}$ long and some $3 \mathrm{~km}$ wide, and has a relatively complex morphology (Fig. 3). The canyon floor has a fairly constant width of about $600 \mathrm{~m}$, and dissymmetric, progressively higher flanks. The northern flank is rather regular, but shows a I-km-wide, 25-m-deep shelf-indented ushaped notch on its top (Fig. 3). The morphology of the southern one is more irregular, and tens of meters high hard-rock structures, probably cemented sediments with scattered coral colonies on top (Orejas and Gili, 2006), can be identified between 200 and $300 \mathrm{~m}$ water depth, separated by small gullies (Fig. 3). The transition between the canyon head and the upper reach is defined in an abrupt widening of the canyon up to $6.5 \mathrm{~km}$, which occurs when the canyon floor reaches a depth of $470 \mathrm{~m}$ (Figs. 2 and 3). Coincidently, two gently-dipping, perched platforms attached to the continental shelf can be identified in both the northern and the southern walls, with depths of 210 and $170 \mathrm{~m}$ respectively.

MAK-IM side-scan records start in the upper reach, at $\sim 600 \mathrm{~m}$ water depth. There, the northern and southern walls display also contrasting morphologies. The northern wall is incised by a series of rounded, amphitheatre-shaped features, interpreted as gullies (Fig. 3). Some of these depressions could as well be related to slope instability processes due to undercutting or oversteepening. On the other hand, the southern wall displays a smoother character in its upper part, and less distinct gullies. A field of strikingly dense and regularly distributed lineations appears in its lowest part, as evidenced on swath bathymetry MAK-IM side-scan sonographs (Figs. 3 and 4). We attribute these lineations to furrows, i.e. a series of parallel, regularly spaced grooves (Flood, 1983). Other interpretations, such as terraces or outcropping edges of exposed beds are discarded. The edges of terraces, which are subhorizontal surfaces, would be parallel to the bathymetric contours and converge up-canyon, but single furrows can be followed from $400 \mathrm{~m}$ down to $800 \mathrm{~m}$ water depth (Figs. 3 and 4) and some of them climb over the southern wall almost up to the shelf break (Fig. 4B). On the other hand, long, straight outcropping strata traces that cut the bathymetric contour lines without changing their orientation (see Fig. 4, when furrows cross the depressed gullies in the southern wall) would exclusively represent vertical strata intersecting the seafloor, which are not imaged at all in a $5 \mathrm{kHz}$ seismic profiles across the lineations (Fig. 5).

Furrows are usually less than $5 \mathrm{~m}$ but up to $10 \mathrm{~m}$ deep, $100 \mathrm{~m}$ in wavelength (fig. 4 in Canals et al., 2006), and are excavated in over-consolidated mud (DeGeest et al., submitted). Cohesions of up to $40 \mathrm{kPa}$ were measured in situ on the same mud type at the inner flank of a nearby canyon (Canals et al., 2006; Gaudin et al., 2006). Some of these furrows can be followed over a distance of $5 \mathrm{~km}$ in the sonographs, but their acoustic response slightly faints across the southern wall gullies (Fig. 4A). Occasionally, individual furrows converge down canyon.

The furrows run roughly parallel to the canyon floor, in a west-east direction, between 625 and $775 \mathrm{~m}$ water depth, where the thalweg widens up to $2 \mathrm{~km}$. At $775 \mathrm{~m}$ water depth, the thalweg narrows down to $350 \mathrm{~m}$ and incises the furrow field (Figs. 3 and 4), which then hangs $50 \mathrm{~m}$ over the canyon floor (Fig. 2). This axial incision, also observed in other canyons in the Gulf of Lion, has been previously described in the Cap de Creus canyon by Baztan et al. (2005). Down-canyon of this incision, between 775 and $920 \mathrm{~m}$ water depth, the furrows can also be observed in the lowest part of the northern wall. The orientations of the furrows in the southern and the northern flanks are not coincident, the latter having a south-eastward direction (Fig. 4), thus displaying a thalweg-parallel orientation, whereas the furrows in the northern flank are oblique to the thalweg. Between water depths of 920 and $1000 \mathrm{~m}$, some furrows can be observed in the thalweg itself. At these depths, a $4 \mathrm{~km}$ long mid-channel 
sediment bar with isolated high-backscatter patches interpreted as mega-ripples can be identified in the sonographs (Fig. 4).

High resolution $5 \mathrm{kHz}$ profiles show several diffraction hyperbolae across the mega-scale furrow field, which are likely caused by the seafloor roughness resulting from the furrows themselves as related to the wavelength of the $5 \mathrm{kHz}$ seismic source (Hollister et al., 1974; Lee and George, 2004). The diffraction hyperbolae overly stratified seismic reflectors (Fig. 5). Within the thalweg, the seabed reflection has a high-amplitude on top of an opaque seismic facies (Fig. 5), representing a sandy lag deposit. A box core obtained from the thalweg at 949 $\mathrm{m}$ water depth contained $24 \mathrm{~cm}$ of clean shelly sand (Nittrouer, pers. comm.). Unconsolidated mud overlying sand has been sampled from $400 \mathrm{~m}$ to $780 \mathrm{~m}$ water depth along the thalweg (DeGeest et al., submitted).

\subsection{Middle canyon}

At the transition between the upper reach and the middle canyon at depths of ca. $1000 \mathrm{~m}$, the Cap de Creus canyon, which turns slightly south-eastwards, is still deeply incised in the margin (Fig. 2). Its northern wall is ca. $500 \mathrm{~m}$ high, and the southern wall accounts over $700 \mathrm{~m}$ high. Although the top of the southern wall is at ca. $300 \mathrm{~m}$ water depth, it represents the shelf break, and thus is in direct connection with the continental shelf (Fig. I).

In this section, furrows on the flanks also display contrasting orientations in the northern and southern flanks. Those in the southern flank have a constant northwest-southeast orientation, whereas furrows in the northern flank draw a turn to the south-southeast (Fig. 6). They are slightly interrupted by sidewall gullies, and rarely diverge down canyon. Subtle furrows are imaged as high as $120 \mathrm{~m}$ above the canyon thalweg in the northern flank, in a region affected by large-scale canyon wall instability (Fig. 6). Down to $1300 \mathrm{~m}$ water depth, furrows in both flanks are parallel or sub-parallel to the canyon direction (Fig. I).

Mega-scale furrow fields in the canyon disappear when the southern wall loses its direct connection with the continental shelf, at ca. $1300 \mathrm{~m}$ water depth. Canyon wall height decreases, and the canyon opens to the lower continental slope (Fig. I). From there downslope, and until it joins the Sète canyon, the Cap de Creus canyon rests on top of the PDSC.

\subsection{Lower canyon}

A steeper short reach at $1600 \mathrm{~m}$ water depth (Figs. I and 7) marks the limit between the middle reach and the lower Cap de Creus canyon. This scarp is the bathymetric representation of the first of a series of SW-NE-oriented steps (Figs. IC and 2) that have been previously identified and related to faults (Baztan et al., 2005) disrupting the seafloor and rooted in the Messinian evaporites (dos Reis et al., 2005). This normal fault results in an increase of the axial slope gradient in a $5 \mathrm{~km}$ long section of the canyon. Downslope the fault, the canyon has a characteristic low axial gradient and is much less incised in the margin (Fig. 2). Closely related to this fault, destabilisation of the lowest part of the northern canyon wall, displayed in MAK-IM sonographs and interpreted as landslide scars and detached sediment blocks occurring over a distance of $3 \mathrm{~km}$, produced a narrowing of the canyon thalweg (Fig. 7). Both the narrowing of the canyon and the increase in axial gradient would entail a localized speed up of along-canyon flowing currents, thus increasing its eroding capability and favouring the creation of thalweg ponds, well-defined intra-canyon depressions, similar to plunge pools in waterfalls (Caress et al., 2002). In the Cap de Creus canyon, these thalweg ponds are up to 1.5 $\mathrm{km}$ long, $200 \mathrm{~m}$ wide and $40 \mathrm{~m}$ deep, as observed from swath bathymetry data (Fig. 7). 
Canyon narrowing occurs also at $1800 \mathrm{~m}$ water depth, when it crosses another of these listric faults (Fig. 8). In this case, the increase in eroding capability of currents is shown by the presence of scours in the canyon floor. On the contrary, relative slow down of currents down-canyon of the ramp and associated minor faults allows sediment deposition and formation of depositional bedforms such as possible mega-ripples observed in the MAK-IM sonographs (Fig. 8). In this part of the lower reach, the Cap de Creus canyon floor widens up to $3.5 \mathrm{~km}$, becomes almost flat (section A in Fig. 2) and hangs over the PDSC limited by a locally $>100 \mathrm{~m}$ high structurally-controlled southern flank (section $\mathrm{G}$ in Fig. 2).

Both the Cap de Creus and the Lacaze-Duthiers canyons converge at $42^{\circ} 13^{\prime} 30^{\prime \prime} \mathrm{N}$ and $4^{\circ} \mathrm{I} 7^{\prime} \mathrm{E}$ at $2140 \mathrm{~m}$ water depth into a less than I-km-wide, 4-km-long narrow gorge that later opens to the Sète canyon (Figs. 2 and 9). Thus, the lower Cap de Creus canyon hangs $280 \mathrm{~m}$ over its own distalmost reach and the lower Sète canyon (Figs. I, 2 and 8). The gorge shows a complex topography, with numerous grooves and other erosive linear morphologies in its walls, as well as wall instability (Fig. 9).

\subsection{Sète canyon distalmost reach}

At $2145 \mathrm{~m}$ water depth, just off the above described gorge, the canyon floor displays linear scours that open to the northeast in a fan-like morphology (Fig. 9B). Only $2 \mathrm{~km}$ away from the gorge mouth, the scours become oriented southeastwards, like the axis of the Sète canyon (Fig. 9C).

The distalmost reaches of the Sète canyon, also imaged with the MAK-IM side-scan sonar, show dozens of irregular to crescent scours, some of them as large as I km wide, $400 \mathrm{~m}$ long and $10 \mathrm{~m}$ deep (Fig. 10). Scours have been observed elsewhere in submarine canyons such as the Stromboli canyon (Kidd et al., 1998), and several crescent to flute-shaped scours were imaged during the very same cruise using the MAK-IM side-scan sonar at short distance of the neo-channel in the Petit-Rhône Neofan and already described by Kenyon et al. (1995), Wynn et al. (2002) and Bonnel et al. (2005). South-eastwards oriented grooves can also be identified in this area, coincident with the orientation of the crescent scours, suggesting that they may result from a similar eroding mechanism (Fig. 10). All these erosive bedforms are a clear indication of bed load sediment transport and along-canyon currents in the lower Sète canyon able to carry such a bed load.

\section{Discussion}

MAK-IM side-scan sonographs reveal that erosion, transport and deposition of sediment along the Cap de Creus canyon are controlled by multiple factors and processes (Fig. II). Erosion occurs in the upper parts of the canyon, where mega-scale furrow fields and an axial incision have been observed. Bedforms of all scales are often reliable evidence for the direction, velocity and persistence of bottom currents or palaeo-currents that are responsible for their formation (Masson et al., 2004). Large scale sedimentary furrows such as those observed in the Cap de Creus canyon typically form in environments which have recurring, directionally stable, and occasionally strong currents (Poppe et al., 2002), achieving peak velocities of $>1.0 \mathrm{~m} \mathrm{~s}^{-1}$ (Flood, 1983; Hamilton and Lugo-Fernandez, 200I; Masson et al., 2004). They have been observed in the deep-sea in areas such as the Faeroe-Shetland Channel (Masson et al., 2004), the northwestern Atlantic margin (Ryan, 1982), the Blake-Bahamas Outer Ridge off the U.S. East Coast (Flood, 1994), and massively at the base of the Sigsbee Escarpment, in the Gulf of Mexico (Bryant et al., 2000; Lee and George, 2004), where individual furrows can be traced for at least $50 \mathrm{~km}$. Recently, they have been described in the Adriatic sea in areas where bottomcurrents likely reach high velocities (Verdicchio and Trincardi, 2006). 
Canals et al. (2006) have proposed that erosion by bed load transport by recurrent dense shelf water cascading, which is more intense in the western canyons of the Gulf of Lions (Palanques et al., 2006), is responsible for the formation of furrow fields in the Cap de Creus canyon. The critical narrowing of the shelf produced by the presence of both the Cap de Creus canyon and the Creus Cape promontory probably favours dense water to enter the canyon by gravity through the southern wall where it is directly connected to the continental shelf (Fig. II). The location of the furrows within the canyon and their orientation is in agreement with this explanation.

The mobilised water mass would cascade mostly through the southern wall and reach the bottom of the canyon, where eastwards-oriented bottom current peak velocities of up to 0.85 $\mathrm{m} \cdot \mathrm{s}^{-1}$ have been measured during a two-month long cascading episode in winter 2005 (Canals et al., 2006), which was particularly cold and windy. The incised thalweg in the upper and middle canyon (Fig. 4) would act as a collector for the near-bottom current and particles transported along furrows. The lack of connectivity between furrows in the southern and the northern flanks across the canyon thalweg (Fig. 4) could demonstrate that the thalweg did not incise an already existing continuous furrow field, but the furrows developed after the axial incision. On the other hand, the present furrow field could be the remains of a previous, continuous furrow field that was later incised by the thalweg, if currents are strong enough not only to create, but to modify the orientation of existing furrows or overprint new ones.

Either way, strong currents capable of forming furrows would be able to reach the northern flank over the axial incision. The topography of the northern flank would deflect the currents forcing them to turn southwards, as shown by furrow orientation on this area (Figs. 4 and 6). The near-bottom current would be almost totally funnelled into the canyon between 1200 and $1300 \mathrm{~m}$ water depth, when furrows in both flanks of the canyon are parallel to the canyon direction (Fig. I). At depths below 1300 m, the current would gradually lose its eroding capability, probably due to the widening of the canyon and to the up-canyon release of the coarser load.

The axial incision has been interpreted as the downcutting of the canyon floor during rejuvenation, by erosion due to hyperpycnal, river-connected turbidity currents during the Last Glacial Maximum (Baztan et al., 2005), which in turn also triggered mass wasting affecting the canyon head (Pratson and Coackley, 1996; Sultan et al., 2007). According to this, the axial incision is the representation of canyon activity during sea-level low-stands, whereas furrow fields look as the imprint of activity during, at least, the present high-stand, when conditions are prone for dense water to form in the flooded shelf. Notwithstanding this, the fact that the Cap de Creus canyon incision produces a critical narrowing of the shelf, favours the entrapment of material transported by along-shore southwards currents, thus increasing the activity of the canyon as a sediment conduit from its head.

The eroded sediment is transported down-canyon to the lower reach, leaving behind lag deposits on the canyon floor observed in sediment cores. Along-canyon currents increase or decrease their velocities depending on the slope gradient and width of the canyon. Thus, alongcanyon currents strong enough to erode sediment in the canyon floor and leave their imprint in the form of erosive bedforms and over-excavation ponds occur across the tectonically controlled ramps in the lower reach, as well as where the canyon narrows due to deposition of canyon wall mass wasting products (Fig. II). Besides, wall instability is one of the factors controlling the morphology of submarine canyons (e.g. Cronin et al., 2005), and the Cap de Creus canyon is not an exception. As observed in MAK-IM side-scan sonar, kilometre-long sections of the northern wall show indications of destabilisation, such as headwall scars and detached blocks, which tend to block the canyon floor (Fig. II). Eventually, along-canyon currents decrease their strength in wider sections of the canyon, allowing sedimentation of suspended load. Nevertheless, bed load transport occurs as demonstrated by the presence of 
mega-ripples in the lower Cap de Creus canyon. Along-canyon currents originated by dense shelf water cascading are able to reach the mouth of the Cap de Creus canyon at 2140 m, as revealed by the intrusion of a cold, turbid dense shelf water mass after the winter 2005 event (Canals et al., 2006).

The Cap de Creus canyon is responsible for the outbuilding of the main part of the PDSC, probably through an old mouth located at the base-of-slope (Figs. I and II) (dos Reis et al., 2005; Jallet and Giresse, 2005). Most of the sediment transported in the past by the canyon possibly accumulated in that area, although canyon activity seems to decrease during the deposition of the upper series of the PDSC, when the Sete canyon is interpreted to have a greater influence (Jallet and Giresse, 2005), as also inferred from the MAK-IM sonographs. In fact, the opening of the Cap de Creus canyon into the Sète canyon is recent (Canals, 1985; dos Reis et al., 2005). Since currents able to erode sediment from the upper canyon reach the junction with the Sète canyon, and several scours and other bedforms indicative of bed load transport have been identified in the lower Sète Canyon immediately downstream of the Cap de Creus Canyon mouth, it has been proved that deposition of sediment transported by the Pyrenean canyons occur presently in the Sète lobe (Droz et al. 200I; Bonnel et al., 2005).

Canals (1985) and Jallet and Giresse (2005) considered that the emplacement of the Cap de Creus canyon was directly controlled by a major growth fault rooted in the underlying Messinian evaporites, and that could have been further incised later related to overall slope destabilisation or relatively recent fault activity. From MAK-IM side-scan sonographs and swath bathymetry data it is clear that the Cap de Creus canyon crosses a region heavily affected by evaporite-related listric faults (Fig. IC). Recent halokinetics may have triggered the canyon wall instabilities observed in the lower reach, partially controlling canyon width and slope and thus indirectly affecting along-canyon current speed. Halokinesis could also be the responsible for the narrow gorge in the distalmost reach of the Cap de Creus canyon, which could have formed to compensate a disequilibrium in the common base level of the Pyrenean canyons relatively to that of the Sète canyon.

Overall, the present morphology of the Cap de Creus canyon, as shown by MAK-IM side-scan sonographs, is a mixture of erosive processes, subsequent sediment transport and deposition, and sediment instability, whereas regional evaporite tectonism adds complexity to the system. Most of the processes shaping the present morphology of the canyon either are or have been recently active.

\section{Conclusions}

The Cap de Creus canyon is located at the limit between the Gulf of Lion and the Catalan margin, in front of the Creus Cape promontory. It can be divided in upper, middle and lower reaches based on morphological criteria. The upper and middle canyon are deeply incised, with steep walls and a flat canyon floor. In the lower canyon there is an alternation of narrow and wider sections. The lower canyon hangs $280 \mathrm{~m}$ over the distalmost reach before entering the Sète canyon.

The Cap de Creus canyon present day morphology is the consequence of several sedimentary processes. Its geographical location produces a critical narrowing of the continental shelf, favouring the entrapment and funnelling of sediment transported by predominant southwardoriented along-shelf currents in the Gulf of Lion. A strikingly dense field of mega-scale furrows is a dominant feature on the southern flank of the upper and middle canyon, which is directly connected to the shelf. Furrows also occur on the lowest parts of the northern wall. Those furrows are most probably created by recurrent dense shelf water cascading episodes. This dense water is able to reach the distalmost Cap de Creus canyon, where it joins the lower 
Sète canyon. In addition, landslide processes in the canyon wall control the canyon width in some sections. Local increases of the canyon axis gradient relate to halokinetic movements of the underlying Messinian evaporites. Transport and depositional bedforms such as mega-ripples have been observed in the lower canyon, whereas large erosive bedforms have been imaged in the distalmost reaches of the Sète canyon, including grooves and crescent scours, indicative of bed load sediment transport.

Overall, these morphological and sedimentary features demonstrate that the Cap de Creus is presently an efficient link between the continental shelf and the deep basin, capable of transporting huge quantities of sediment by a combination of external forcings and sedimentary processes.

\section{Acknowledgements}

This research was supported by the HERMES project, EC contract no GOCE-CT-20055 I I234, funded by the European Commission's Sixth Framework Programme under the priority 'Sustainable Development, Global Change and Ecosystems', the EUROSTRATAFORM project (EVK3-2002-00079) from the EC-VFP; also by project SPACOMA (REN2002-I I 2 I7EMAR) of the EUROCORES Program about EUROMARGINS of the European Science Foundation, and a Generalitat de Catalunya "Grups de Recerca Consolidats" grant (2005 SGR00152). The EURODOM Research Training Network (HPRN-CT-2002-002I2) is also acknowledged. We thank $A$. Camerlenghi for his thoughtful comments on furrow field origins. Officers, crews, technicians and students involved in sea-going work have provided essential help during data acquisition. Fellowship holders acknowledge their respective funding agencies. J.F. is supported by the European Community's Sixth Framework Programme through a Marie Curie Outgoing International Fellowship. The publication reflects only the views of the authors; the EC is not liable for any use that may be made of this paper. 


\section{References}

Alonso, B., Canals, M., Got, H., Maldonado, A., 199I. Sea valleys and related depositional systems in the Gulf of Lion and Ebro Continental Margins. AAPG Bull. 75, II95-12। 4.

Babonneau, N., Savoye, B., Cremer, M., Klein, B., 2002. Morphology and architecture of the present canyon and channel system of the Zaire deep-sea fan. Mar. Petrol. Geol. 19, 445-467.

Baztan, J., Berné, S., Olivet, J.L., Rabineau, M., Aslanian, D., Gaudin, M., Réhault, J.P., Canals, M., 2005. Axial incision: The key to understand submarine canyon evolution (in the western Gulf of Lion). Mar. Petrol. Geol. 22, 805-826.

Bellaiche, G., Orsolini, P., Petit-Perrin, B., Berthon, J.L., Ravenne, C., Coutellier, V., Droz, L., Aloisi, J.C., Got, H., Mear, Y., Monaco, A., Auzende, J.M., Beuzart, P., Monti, S., 1983. Sea-beam study on the Rhone deep sea fan and its vector canyon. C. R. Acad. Sci., Ser. Ila: Sci. Terre Planets, 296, 579-583.

Berné, S., Gorini, C., 2005. The Gulf of Lions: An overview of recent studies within the French “Margins” programme. Mar. Petrol. Geol. 22, 691-693.

Berné S., Loubrieu B., the CALMAR shipboard party, 1999. Canyons and recent sedimentary processes on the Western Gulf of Lions margin. C. R. Acad. Sci., Ser. Ila: Sci. Terre Planets, 328, 47I-477.

Berné, S., Carré, B., Loubrieu, B., Mazé, J.P., Morvan, L., Normand, A., 2004. Le Golfe du Lion, Carte morpho-bathymétrique, Ifremer, Brest.

Bonnel, C., Dennielou, B., Berné, S., Mulder, T., Droz, L., 2005. Architecture and depositional pattern of the Rhône Neofan and recent gravity activity in the Gulf of Lions (Western Mediterranean). Mar. Petrol. Geol. 22, 827-843.

Bryant, W.R., Dellapenna, T., Silva, A., Dunlap, W., Bean, D., 2000. Massive Bed-Forms, Mega-Furrows, on the Continental Rise at the Base of Sigsbee Escarpment, Northwest Gulf of Maine. AAPG Bull. 84, 1673.

Burollet, P.F., Byramjee, R., 1974. Évolution géodynamique nèogène de la Méditerranée occidentale. C. R. Acad. Sci., Ser. Ila: Sci. Terre Planets, 278, I32I-I 324.

Canals, M., 1985. Estructura sedimentaria y evolución morfológica del talud y el glacis continentales del Golfo de León: fenómenos de desestabilización de la cobertera sedimentaria Plio-Cuaternaria. PhD Thesis, Universitat de Barcelona, Spain, 618 pp.

Canals, M., Casamor, J.L., Urgeles, R., Lastras, G., Calafat, A.M., De Batist, M., Masson, D., Berné, S., Alonso, B., Hughes-Clarke, J.E., 2000. The Ebro continental margin, Western Mediterranean Sea: Interplay between canyon-channel systems and mass wasting processes, in: Nelson, C.H., Weimer, P. (Eds.), Deep-water Reservoirs of the World. GCSSEPM Foundation 20th Annual Research Conference, Houston, Texas, USA, Pp. I52-I74.

Canals, M., Puig, P., Durrieu de Madron, X., Heussner, S., Palanques, A., Fabres, J., 2006. Flushing and reshaping submarine canyons by dense shelf water cascading. Nature, 444, 354-357.

Caress, D.W., Greene, H.G., Paull, C.K., 2002. Plunge pools in submarine canyons. AGU Fall Meeting 2002, abstract n. OS7IC-03I5.

Carson, B., Baker, E.T., Hickey, B.M., Nittrouer, C.A., DeMaster, D.J., Thorbjarnarson, K.W. Snyder, G.W., 1986. Modern sediment dispersal and accumulation in Quinault submarine canyon - a summary. Mar. Geol. 7I, I-I3.

Cirac, P., Bourillet, J.F., Griboulard, R., Normand, A., Mulder, T., 200I. Le canyon de Capbreton: nouvelles approches morphostructurales et morphosédimentaires. Premiers résultats de la campagne Itsas (et l'équipe Itsas). C. R. Acad. Sci., Ser. Ila: Sci. Terre Planets, 332, 447-455. 
Cronin, B.T., Akhmetzhanov, A.M., Mazzini, A., Akhmanov, G., Ivanov, M., Kenyon, N.H., TTR-I0 Shipboard Scientists, 2005. Morphology, evolution and fill: Implications for sand and mud distribution in filling deep-water canyons and slope channel complexes. Sediment. Geol. 179, 7I-97.

Daly, R.A., I 936. Origin of submarine “canyons”. Am. J. Sci. 31, 40 I-420.

DeGeest, A.L., Mullenbach, B.L., Puig, P., Nittrouer, C.A., Drexler, T.M., Durreu de Madron, X., Orange, D.L., submitted. Sediment accumulation in the western Gulf of Lions, France: The role of Cap de Creus Canyon in linking shelf and slope sediment dispersal systems. Submitted to Continental Shelf Research.

dos Reis, A.T., Gorini, C., Mauffret, A., Mepen, M., 2004. Stratigraphic architecture of the PyreneoLanguedocian submarine fan, Gulf of Lions, Western Mediterranean Sea. C. R. Geosci. 336, I25-I36.

dos Reis, A.T., Gorini, C., Mauffret, A., 2005. Implications of salt-sediment interactions on the architecture of the Gulf of Lions deep-water sedimentary systems - western Mediterranean Sea. Mar. Petrol. Geol. 22, 7I3-746.

Droz, L., 1983. L'éventail sous-marin profond du Rhône (Golfe du Lion): grands traits morphologiques et structure semi-profonde. Doctoral thesis, Université de Paris VI, 195 PP.

Droz, L., Rigaut, F., Cochonat, P., Tofani, R., 1996. Morphology and recent evolution of the Zaire turbidite system Gulf of Guinea. Geol. Soc. Am. Bull. 108, 253-269.

Droz, L., Kergoat, R., Cochonat, P., Berné, S., 200I. Recent sedimentary events in the western Gulf of Lions (Western Mediterranean). Mar. Geol. I76, 23-37.

Durrieu de Madron, X., 1994. Hydrography and nepheloid structures in the Grand-Rhône canyon. Cont. Shelf Res. 14, 457-477.

Farre, J.A., McGregor, B.A., Ryan, W.B.F., Robb, J.M., 1983. Breaching the shelfbreak: Passage from youthful to mature phase in submarine canyon evolution, in: Stanley, D.J., Moore, G.T. (Eds.), The Shelfbreak: Critical Interface on Continental Margins. Soc. Econ. Paleontol. Mineral. Sp. Publ. 33, 25-39.

Farre, J.A., 1987. Surficial geology of the continental margin offshore New Jersey in the vicinity of Deep Sea Drilling Project Sites 612 and 613, in: Poag, C.W., Watts, A.B. (Eds.), Init. Rep. Deep Sea Drill. Proj., 95. U.S. Gov. Print. Office, Washington, DC, Pp. 725-759.

Flood, R.D., 1983. Classification of sedimentary furrows and a model for furrow initiation and evolution. Geol. Soc. Am. Bull. 94, 630-639.

Flood, R.D., 1994. Abyssal bedforms as indicators of changing bottom current flow: examples from the U.S. East Coast continental rise. Paleoceanography, 9(6), 1049-1060.

Gardner, W.D., 1989. Baltimore Canyon as a modern conduit of sediment to the deep sea. Deep-Sea Res. 36, 323-358.

Gaudin, M., Berné, S., Jouanneau, J.M., Palanques, A., Puig, P., Mulder, T., Cirac, P., Rabineau, M., Imbert, $P ., 2006$. Massive sand beds attributed to deposition by dense water cascades in the Bourcart canyon head, Gulf of Lions (northwestern Mediterranean Sea). Mar. Geol., 234: II I-I 28.

Got, H., 1973. Etude des corrélations tectonique-sédimentation au cours de l'historie quaternaire du précontinent Pyrénéo-Catalan. PhD Thesis, Université des Sciences et Techniques du Languedoc, France, 294 pp.

Got, H., Stanley, D.J., 1975. Sedimentation in two Catalonian canyons, Northwestern Mediterranean. Mar. Geol. 16, M9I-MI00.

Gueguen, E., Doglioni, C., Fernández, M., 1998. On the post-25 Ma geodynamic evolution of the western Mediterranean. Tectonophysics, 298, 259-269. 
Hagen, R.A., Bergersen, D.D., Moberly R., Coulbourn, W.T., 1994. Morphology of a large meandering submarine canyon system on the Peru-Chile forearc. Mar. Geol. I19, 7-37.

Hamilton, P., Lugo-Fernandez, A., 200I. Observations of high speed deep currents in the northern Gulf of Mexico. Geophys. Res. Lett. 28, 2867-2870.

Hollister, C.D., Flood, R.D., Johnson, D.A., Lonsdale, P.F., Southard, J.B., 1974. Abyssal furrows and hyperbolic echo traces on the Bahama Outer Ridge. Geology, 2, 395-400.

Hsü, K.J., 1977. The history of the Mediterranean salinity crisis. Nature, 267, 399-403.

Jallet, L., Giresse, P., 2005. Construction of the Pyreneo-Languedocian Sedimentary Ridge and associated sediment waves in the deep western Gulf of Lions (Western Mediterranean). Mar. Petrol. Geol. 22, 865888.

Kenyon, N.H., Millington, J., Droz, L., Ivanov, M.K., 1995. Scour holes in a channel-lobe transition zone on the Rhône cone, in: Pickering, K.T., Hiscott, R.N., Kenyon, N.H., Lucchi, F.R., Smith, R.D.A., (Eds.), Atlas of Deep-water Environments: Architectural Styles in Turbidite Systems. Chapman and Hall, London, pp. 212-215.

Kidd, R.B., Lucchi, R.G., Gee, M., Woodside, J.M., 1998. Sedimentary processes in the Stromboli Canyon and Marsili Basin, SE Tyrrhenian Sea: results from side-scan sonar surveys. Geo-Mar. Lett. I8, I46-I54.

Laursen, J., Normark, W.R., 2002. Late Quaternary evolution of the San Antonio submarine canyon in the cental Chile forearc ( $\left.33^{\circ} \mathrm{S}\right)$. Mar. Geol. 188, 365-390.

Le Pichon, X., Pautot, G., Auzende, J.M., Olivet, J.L., I97I. La Méditerranée occidentale depuis l'Oligocène. Schéma d'évolution. Earth Planet. Sc. Lett. 13, I45-I52.

Lee, Y.D., George, R.A., 2004. High-resolution geological AUV survey results across a portion of the eastern Sigsbee Escarpment. AAPG Bull. 88, 747-764.

Lewis, K.B., Barnes, P.M., 1999. Kaikoura canyon, New Zealand: active conduit from near-shore sediment zones to trench-axis channel. Mar. Geol. 162, 39-69.

Maillard, A., Mauffret, A., 1999. Crustal structure and riftogenesis of the Valencia Trough (north-western Mediterranean Sea). Basin Res. II, 357-379.

Masson, D.G., Wynn, R.B., Bett, B.J., 2004. Sedimentary environment of the Faroe-Shetland and Faroe Bank Channels, NE Atlantic and the use of bedforms as indicators of bottom current velocity in the deep ocean. Sedimentology, 5I, I207-I24I

May, J.A., Warme, J.E., Slater, R.A., 1983. Role of submarine canyons on shelfbreak erosion and sedimentation: modern and ancient examples, in: Stanley, D.J., Moore, G.T. (Eds.), The Shelfbreak: Critical Interface on continental Margins. Soc. Econ. Paleontol. Mineral. Sp. Publ. 33, 3I5-332.

Méar, Y., 1984. Séquences et unités sédimentaires du glacis rhodanien. $3^{\text {rd }}$ cycle thesis. Université de Perpignan, 223 pp.

Millot, C.A., 1990. The Gulf of Lions' hydrodynamic. Cont. Shelf Res. 10, 885-894.

Mullenbach, B.L., Nittrouer, C.A., Puig, P., Orange, D.L., 2004. Sediment deposition in a modern submarine canyon: Eel Canyon, northern California. Mar. Geol. 2 II, I0I-II 9.

Nelson, C.H., Normark, W.R., Bouma, A.H., Carlson, P.R., 1978. Thin-bedded turbidites in modern submarine canyons and fans, in: Stanley, D.J., Kelling, G. (Eds.), Sedimentation in Submarine Canyons, Fans, and Trenches. Dowden, Hutchinson, and Ross, Stroudsburg, PA, PP. I77-I89.

Normark, W.R., Piper, D.J.W., 1969. Deep-sea fan valleys, past and present. Geol. Soc. Am. Bull. 80, I859-|866. 
Orejas, C., Gili, J.M., 2006. Occurence of coral species off Cape de Creus, western Mediterranean, investigated during cruise CORAL II. Institut de Ciències del Mar, Barcelona, PANGAEA, doi:I0.1594/PANGAEA.39689I.

Palanques, A., Durrieu de Madron, X., Puig, P., Fabrés, J., Guillén, J., Calafat, A., Canals, M., Heussner, S., Bonnin, J., 2006. Suspended sediment fluxes and transport processes in the Gulf of Lions submarine canyons. The role of storms and dense water cascading. Mar. Geol. 234: 43-6I.

Pont, D., Simonnet, J.P., Walter, A.V., 2002. Medium-term changes in suspended sediment delivery to the ocean: consequences of catchment heterogeneity and river management (Rhône River, France). Estuar. Coast. Shelf S. 54, I-I8.

Popescu, I., Lericolais, G., Panin, N., Normand, A., Dinu, C., Le Drezen, E., 2004. The Danube submarine canyon (Black Sea): morphology and sedimentary processes. Mar. Geol. 206, 249-265.

Poppe, L.J., Knebel, H.J., Lewis, R.S., DiGiacomo-Cohen, M.L., 2002. Processes controlling the remobilization of surficial sediment and formation of sedimentary furrows in north-central Long Island Sound. J. Coast. Res. 18, 74I-750.

Pratson, L, Coakley, B.J., 1996. A model for the headward erosion of submarine canyons induced by downslope-eroding sediment flows. Geol. Soc. Am. Bull. 108, 225-234.

Rabineau, M., Berné, S., Aslanian, D, Olivet, J.L., Joseph, Ph., Guillocheau, F., Bourillet, J.F., Ledrezen, E., Granjeon, D., 2005. Sedimentary sequences in the Gulf of Lion: A record of 100,000 years climatic cycles. Mar. Petrol. Geol. 22, 775-804.

Réhault, J.P., Boillot, G., Mauffret, A., 1984. The western Mediterranean Basin, geological evolution. Mar. Geol. 55, 447-477.

Ryan, W.B.F., 1982. Imaging of submarine landslides with wide-swath sonar, in: Saxov, S., Nieuwenhuis, J.K. (Eds.), Marine Slides and Other Mass Movements. Plenum Press, New York, Pp. I75- 188.

Savoye, B., Piper, D.J.W., Droz, L., 1993. Plio-Pleistocene evolution of the Var deep-sea fan off the French Riviera. Mar. Petrol. Geol. 10, 550-57I.

Shanmugam, G., Moiola, R.J., Damuth, J.E., 1985. Eustatic control of submarine fan development, in: Bouma, A.H., Normark, W.R., Barnes, N.E. (Eds.), Submarine Fans and Related Turbidite Systems, Springer-Verlag, New York, pp. 23-28.

Shepard, F.P., I98I. Submarine canyons: multiple causes and long-time persistence. AAPG Bull. 65, 10621077.

Shepard, F.P., Dill, R.F., 1966. Submarine canyons and other sea valleys. Rand McNally, Chicago, II., 38I PP.

Soh, W., Tokuyama, H., 2002. Rejuvenation of submarine canyon associated with ridge subduction, Tenryu canyon, off Tokai, central Japan. Mar. Geol. 187, 203-220.

Sultan, N., Gaudin, M., Berne, S., Canals, M., Urgeles, R., Lafuerza, S., 2007. Analysis of slope failures in submarine canyon heads: An example from the Gulf of Lions. J. Geophys. Res., I I2: F0I009.

Tesson, M., Gensous, B., Naudin, J.J., Chaignon, V., Bresoli, A., 1998. Carte morpho-bathymétrique de la plate-forme du golfe du Lion : un outil pour la reconnaissance et l'analyse des modifications environnementales récents. C. R. Acad. Sci., Ser. Ila: Sci. Terre Planets, 327, 54 I-547.

Twichell, D.C., Roberts, D.G., 1982. Morphology, distribution, and development of submarine canyons on the United States Atlantic continental slope between Hudson and Baltimore Canyons. Geology, I0, 408-4I2. 
Verdicchio, G., Trincardi, F., 2006. Short-distance variability in slope bed-forms along the Southwestern Adriatic Margin (Central Mediterranean). Mar. Geol. 234, 27I-292.

Wessel, P., Smith, W.H.F., 1998. New, improved version of the Generic Mapping Tools Released. Eos Trans. Am. Geophys. U. 79, 579.

Wynn, R.B., Kenyon, N.H., Masson, D.G., Stow, D.A.V., Weaver, P.P.E., 2002. Characterization and recognition of deep-water channel-lobe transition zones. AAPG Bull. 86, I44I-|46. 


\section{Figure Captions}

Fig. I. (A) Multibeam-derived bathymetry contour map of the Cap de Creus canyon and surrounding areas. Contours every $100 \mathrm{~m}$. Data limit is shown with a dotted line. CCC: Cap de Creus canyon; LDC: Lacaze-Duthiers canyon; PC: Pruvot canyon; AC: Aude canyon; SC: Sète canyon; PDSC: Pyrenean canyon deep sedimentary complex. Location of other figures in this article is also provided. (B) Multibeam-derived bathymetry shadow-relief map of the Cap de Creus canyon and surrounding areas. Contours every $250 \mathrm{~m}$. (C) Multibeam-derived bathymetry slope gradient map (white, red and green, higher slope gradients) of the Cap de Creus canyon and surrounding areas. Contours every $250 \mathrm{~m}$. Location of bathymetric sections in Fig. 2 is shown, as well as listric faults in the lower canyon (dos Reis et al., 2005).

Fig. 2. Bathymetric sections along (top $A-A$ ') and across (B to I) the Cap de Creus canyon and the distal reach of the Sète canyon, as well as axial slope gradient profile (bottom $A-A^{\prime}$ ). The canyon head, upper, middle and lower reaches of the Cap de Creus canyon are differentiated. All bathymetric sections are plotted at the same vertical and horizontal scales. Note location of figures along the section.

Fig. 3. (A) Simrad EM-300 swath bathymetry map and (B) pseudo-3D view of the Cap de Creus head and upper reach, showing the different morphologies of the northern canyon wall, dissected by round-shaped gullies, and the southern canyon wall, where the furrow field can be identified from ca. $500 \mathrm{~m}$ water depth. The white dotted line limits the head and the upper canyon. Other features such as the hard-rock structures and the notch in the canyon head are commented in the text. Partial location of Fig. 4 is shown for reference.

Fig. 4. MAK-IM side-scan sonograph (A) and its interpretation (B) from part of the upper reach of the Cap de Creus canyon. The morphology and orientation of mega-scale furrows are perfectly imaged, as well as the incision of the thalweg (zoom C), and the mid-channel sediment bar and possible mega-ripples (zoom D). Note that furrows faint across sidewall gullies, marked by dotted arrows, except the one which crosses profile in Fig. 5. Location of $B$ in Fig. I and partially in Fig. 3. Locations of zooms $C$ and $D$ is shown in $A$.

Fig. 5. Very-high resolution $5 \mathrm{kHz}$ profile along the canyon floor of the Cap de Creus canyon upper reach. The mega-scale furrow field shows diffraction hyperbolae due to seafloor roughness. The thalweg is characterized by an opaque seismic reflector, related to sandy lag deposits. The mid-channel sediment has almost no seismic response probably because it is very obliquely crossed. Location of the profile is provided in Fig. 4.

Fig. 6. MAK-IM side-scan sonograph (A) and its interpretation (B) from part of the middle Cap de Creus canyon. Note that the lack of connectivity between the W-E orientation of the furrows in the southern flank and the orientation of the furrows in the northern flank (zoom C, located in A), which become thalweg-convergent downcanyon. Location of B in Fig. I.

Fig. 7. MAK-IM side-scan sonographs ( $A$ and $B$ ) and their interpretation $(C)$ from the limit between the middle and lower Cap de Creus canyon. Note destabilisation in the northern canyon wall, narrowing the canyon floor and subsequent thalweg ponds. Location of $C$ in Fig. I.

Fig. 8. MAK-IM side-scan sonographs (A and $B$ ) and their interpretation (C) from the lower Cap de Creus canyon. Note the existence of scouring when the canyon crosses the ramp to 
the west, the presence of faults reaching the sea-floor, as well as possible mega-ripples when the canyon widens. Location of $\mathrm{C}$ in Fig. I.

Fig. 9. MAK-IM side-scan sonographs (A, B and $C)$ and their interpretation (D) from the confluence of the Cap de Creus canyon and the Lacaze-Duthiers canyon into the Sète canyon. Note that the first two canyons hang $280 \mathrm{~m}$ over their own distal reach and the lower Sète canyon, through a narrow gorge where grooves can be identified. See also the presence of scours in the Sète canyon floor. Location of D in Fig. I.

Fig. 10. MAK-IM side-scan sonograph (A) and very-high resolution $5 \mathrm{kHz}$ profile along the canyon floor of the Sète canyon distalmost reach, showing deep crescent scours and furrows indicative of recent bottom-current activity at depths over $2100 \mathrm{~m}$. Location of profile is shown in $A$.

Fig. I I. Sketch summarizing the recent processes taking place in the Cap de Creus canyon. 


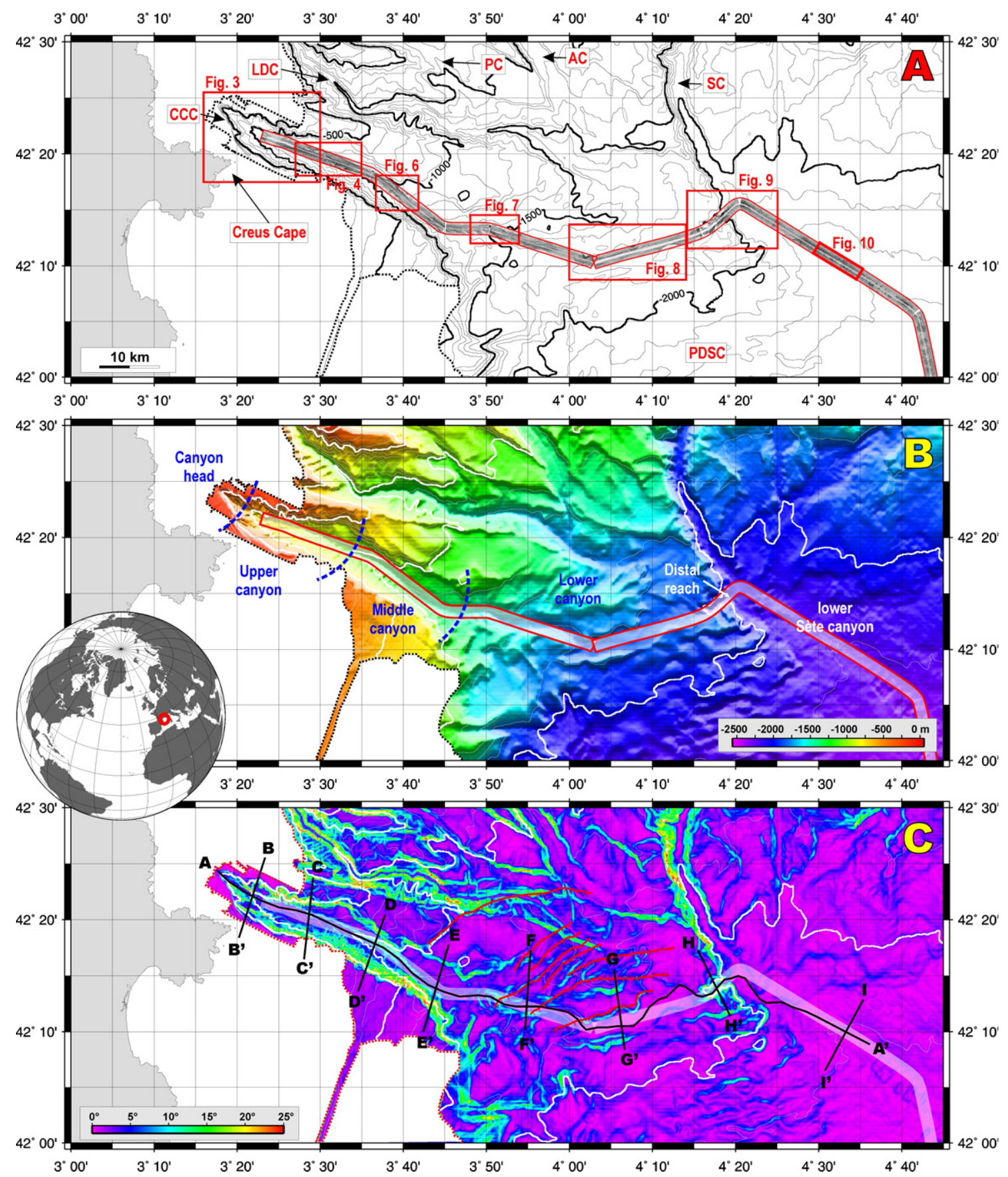

Fig. I 


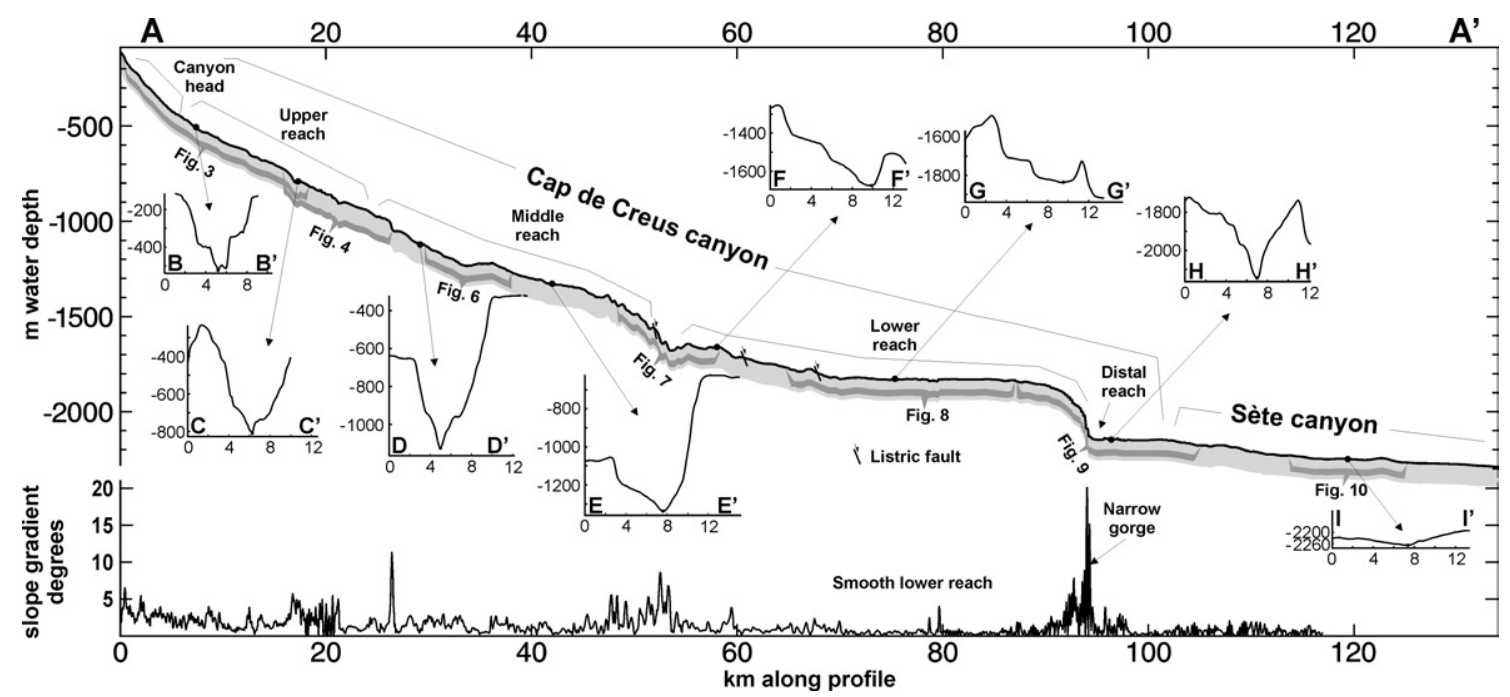

Fig. 2 

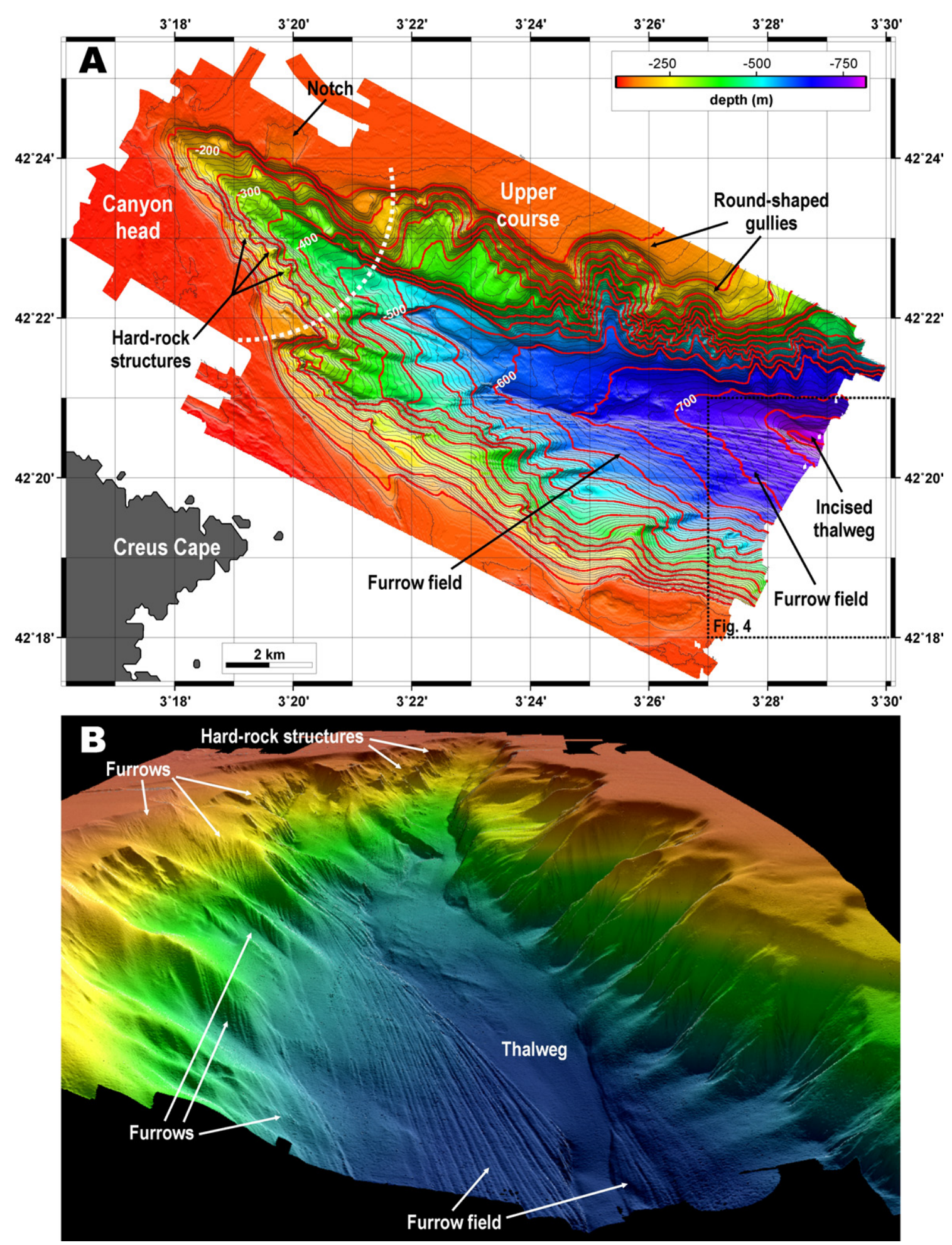

Fig. 3 

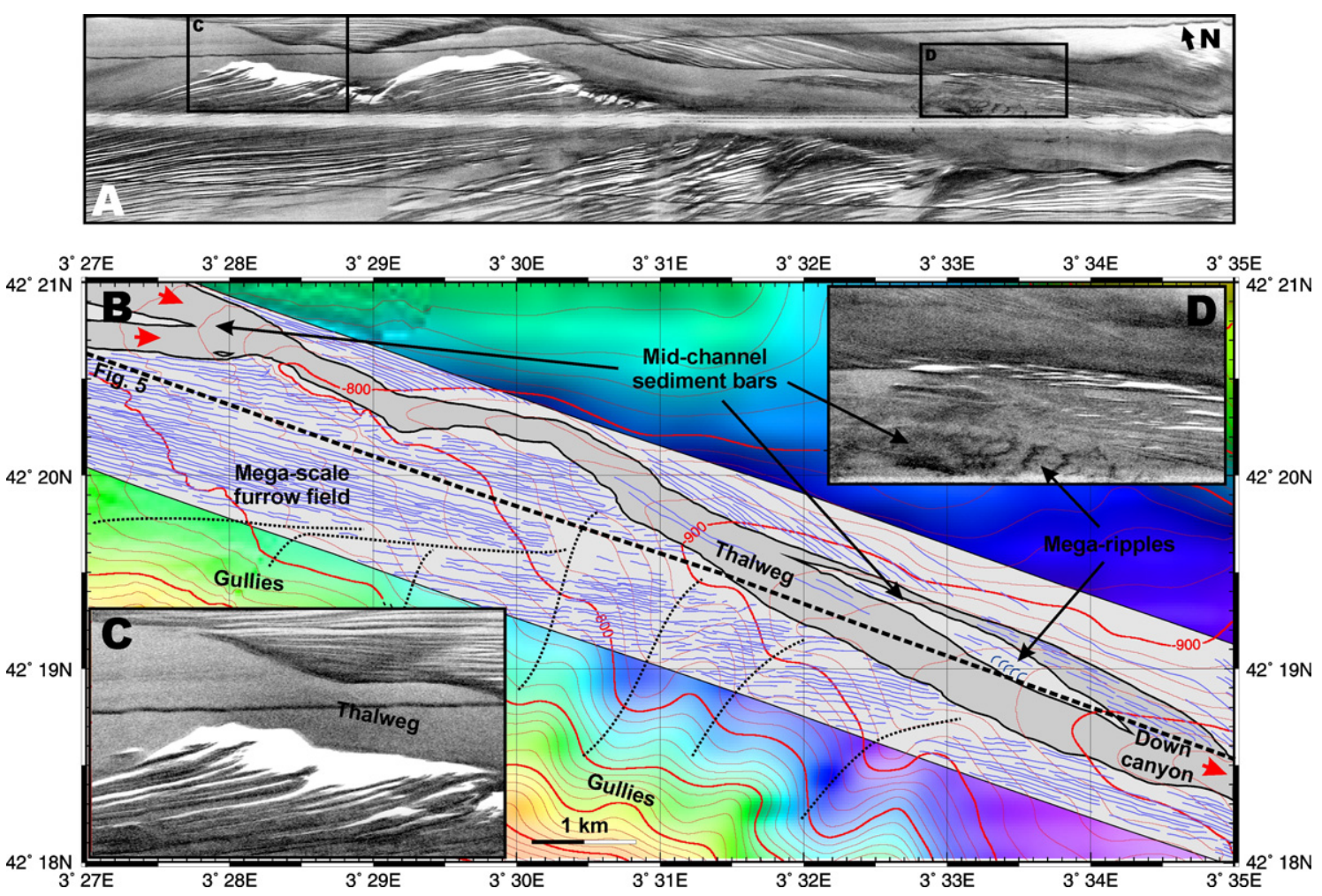

Fig. 4 


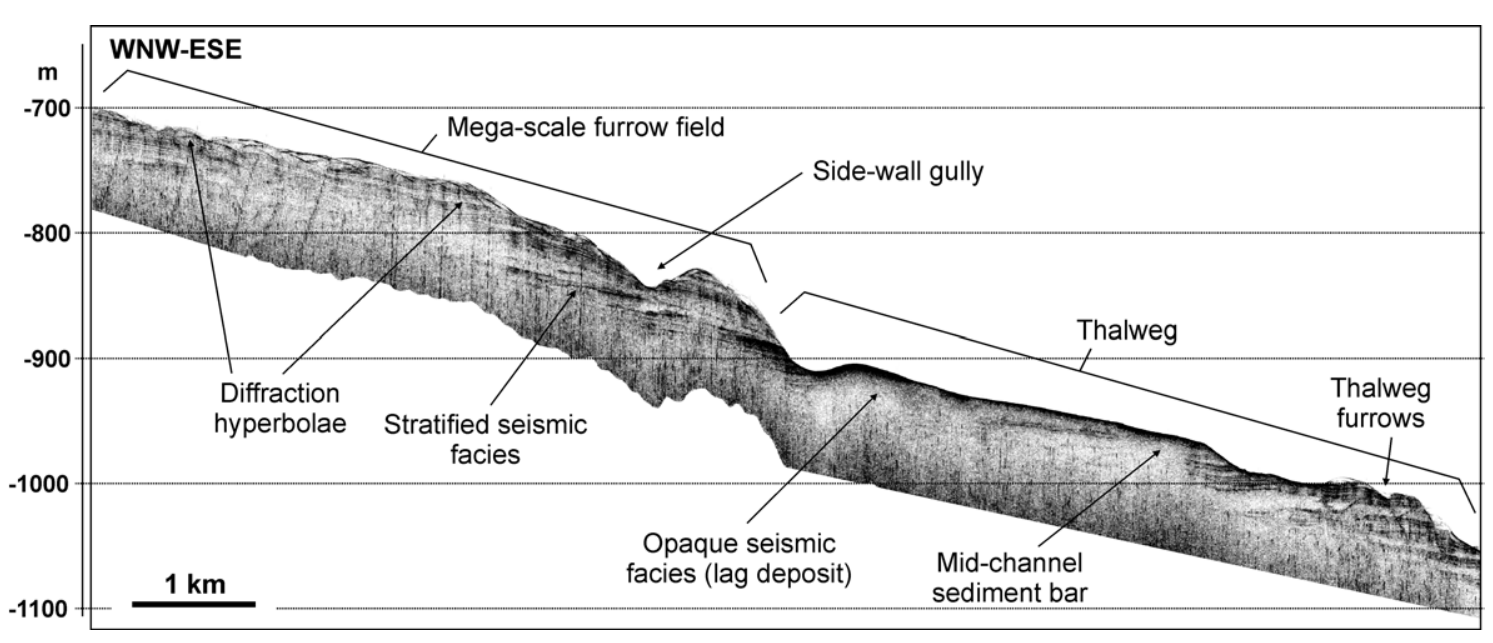

Fig. 5 

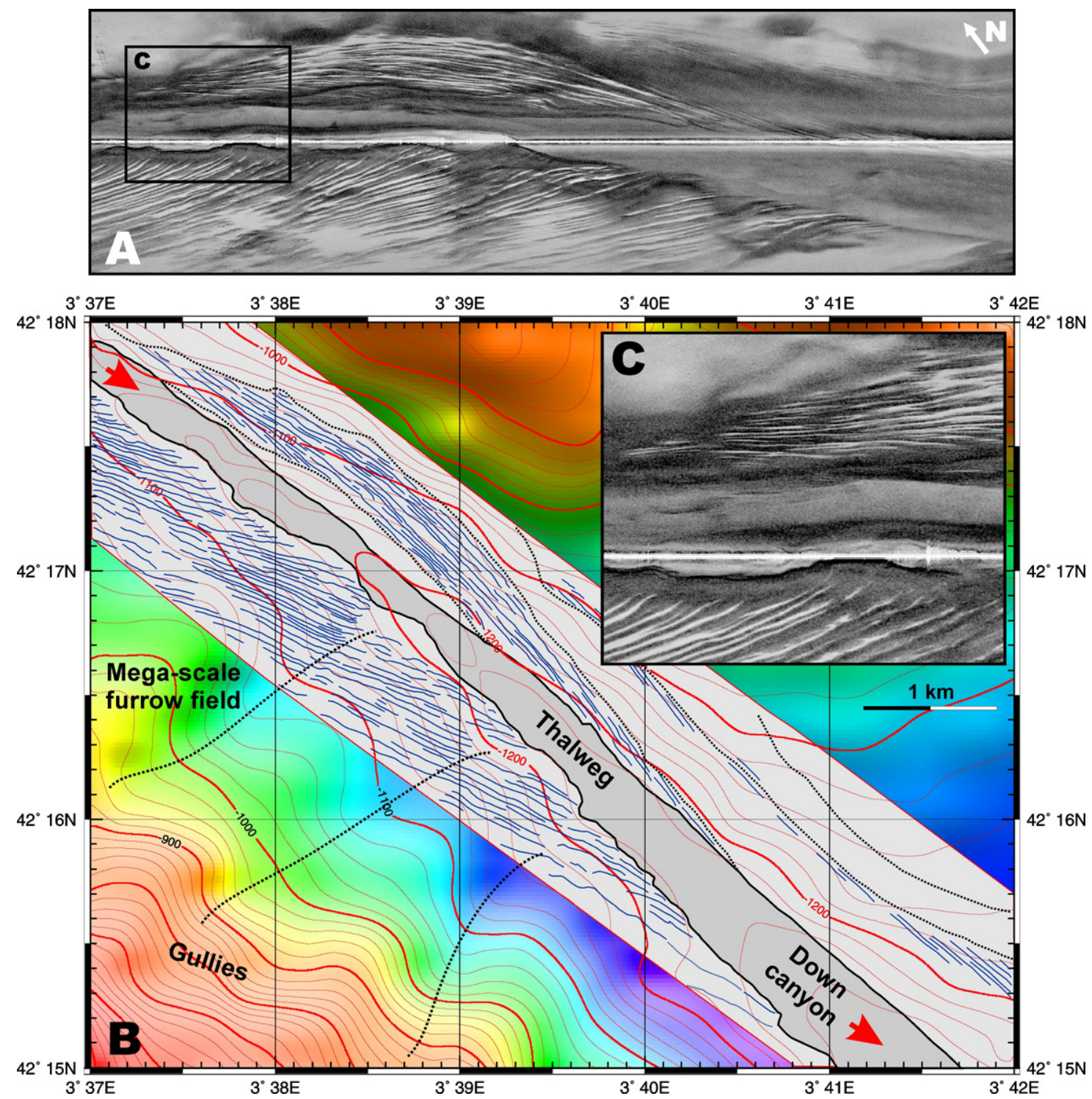

Fig. 6 

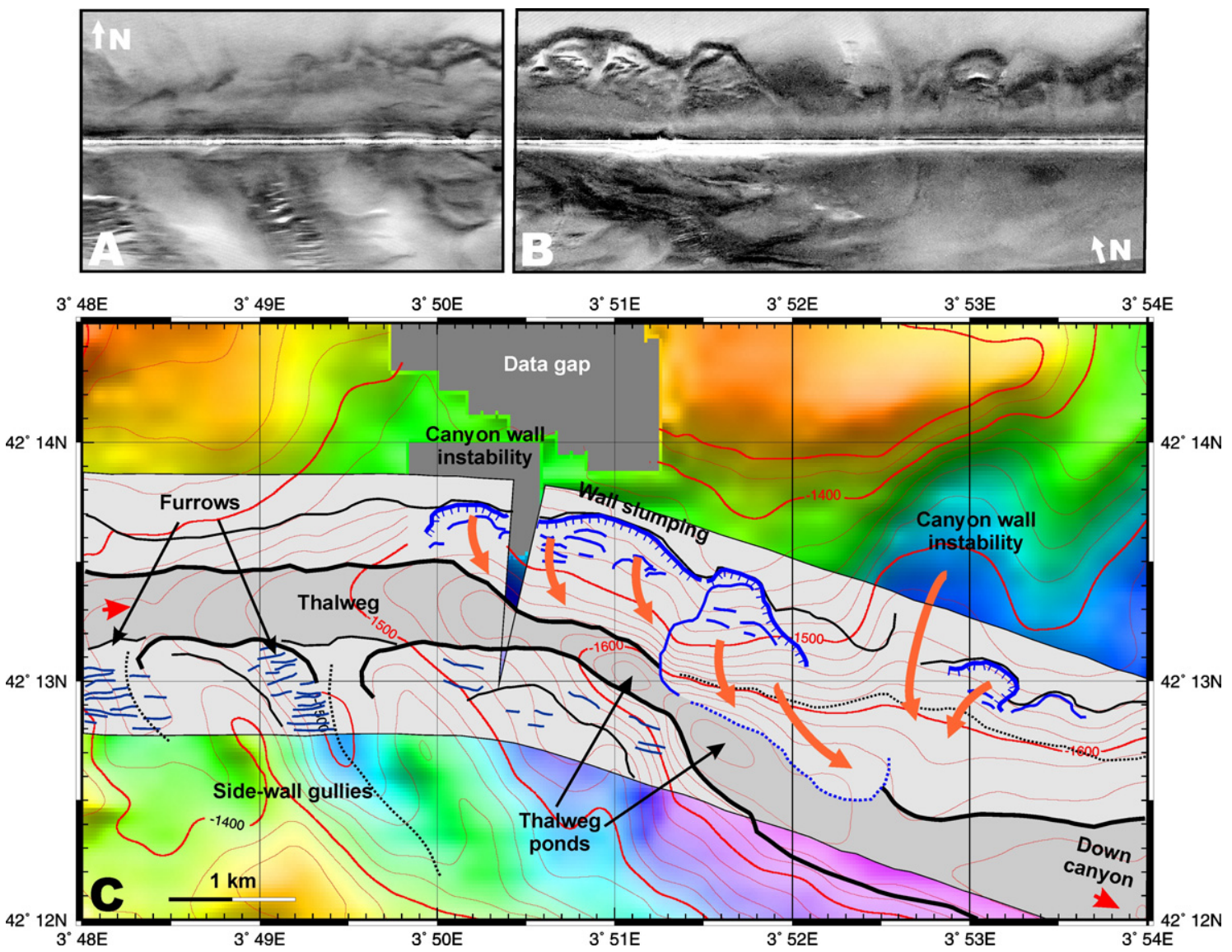

Fig. 7. 


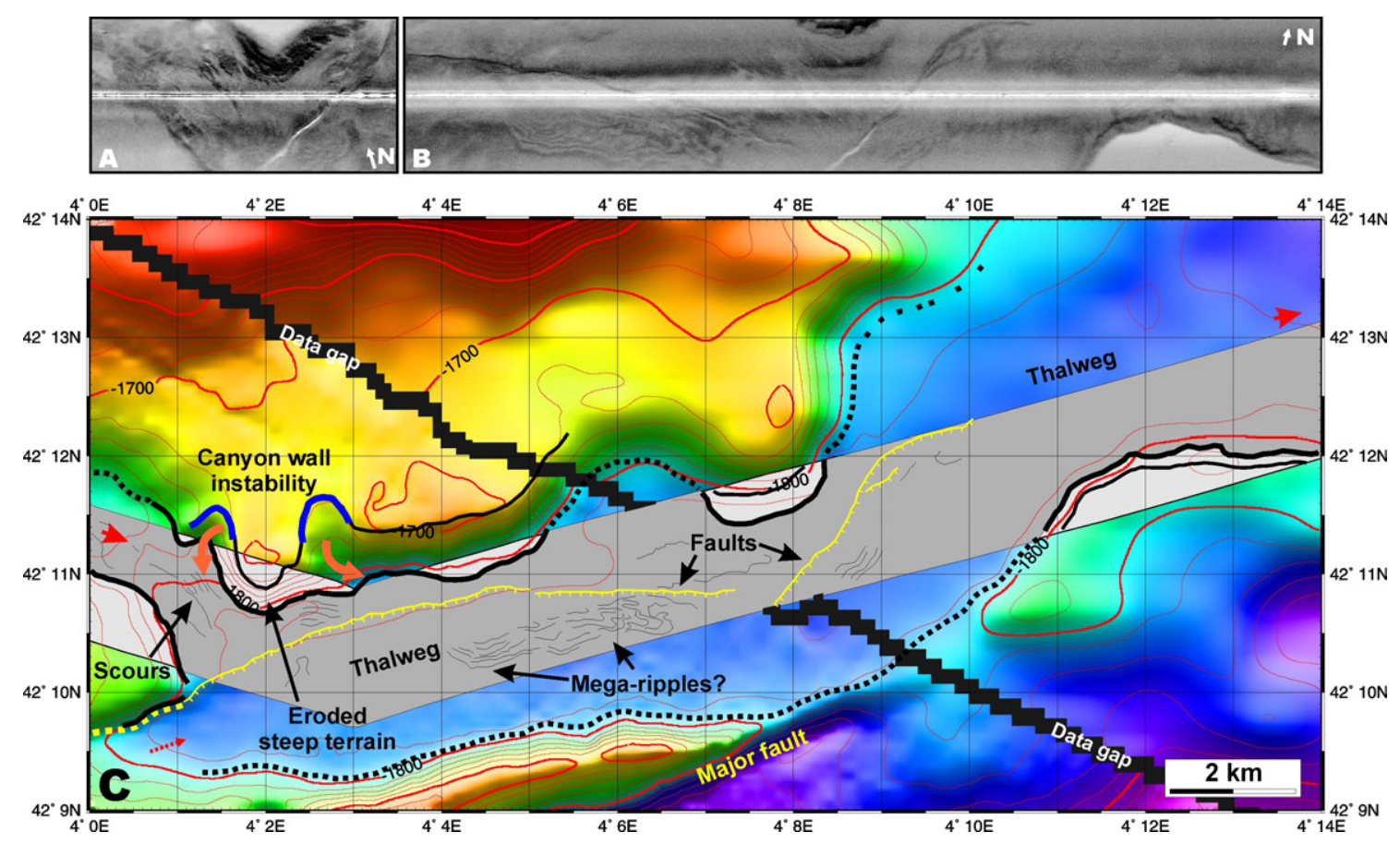

Fig. 8 


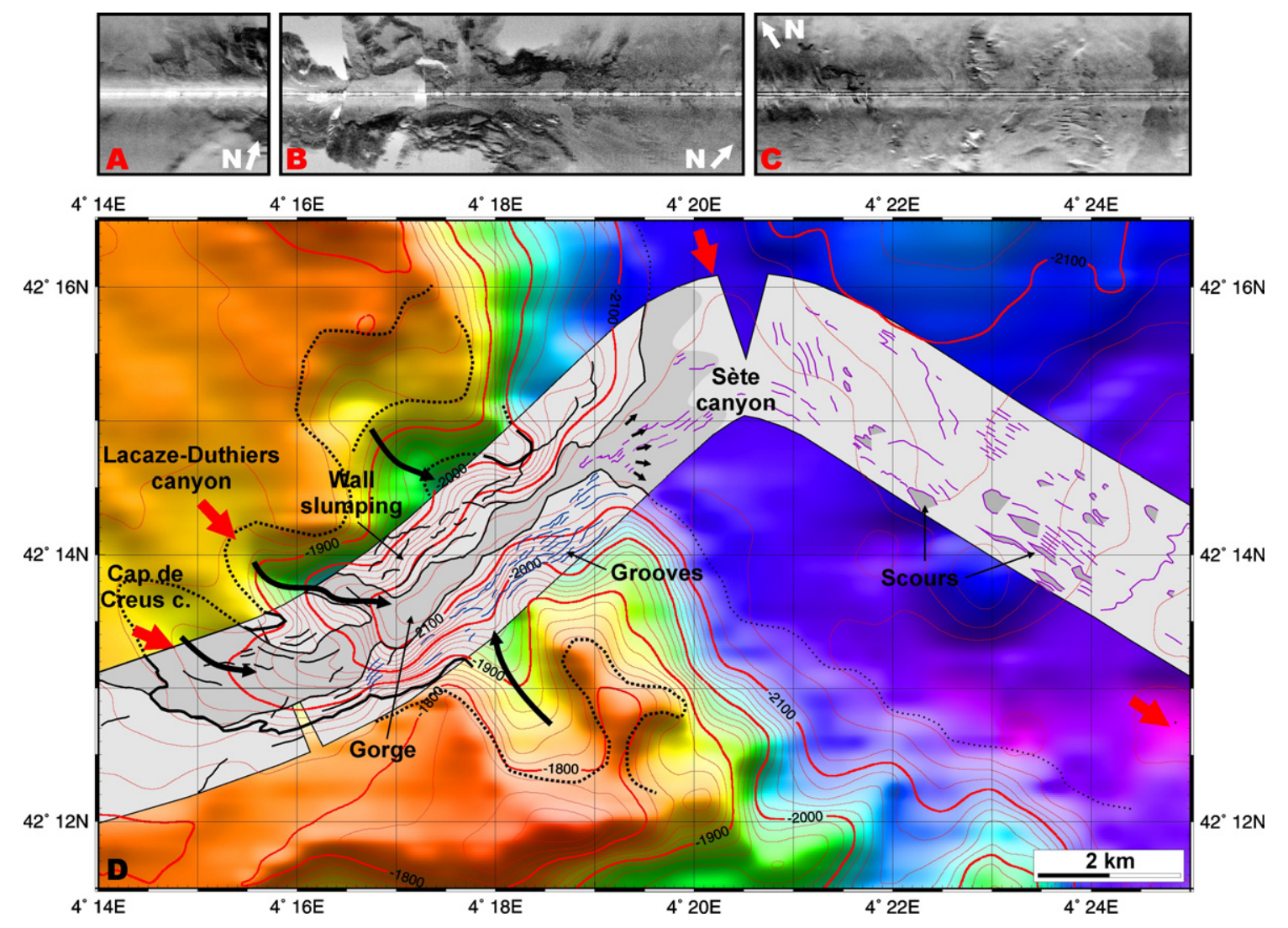

Fig. 9 


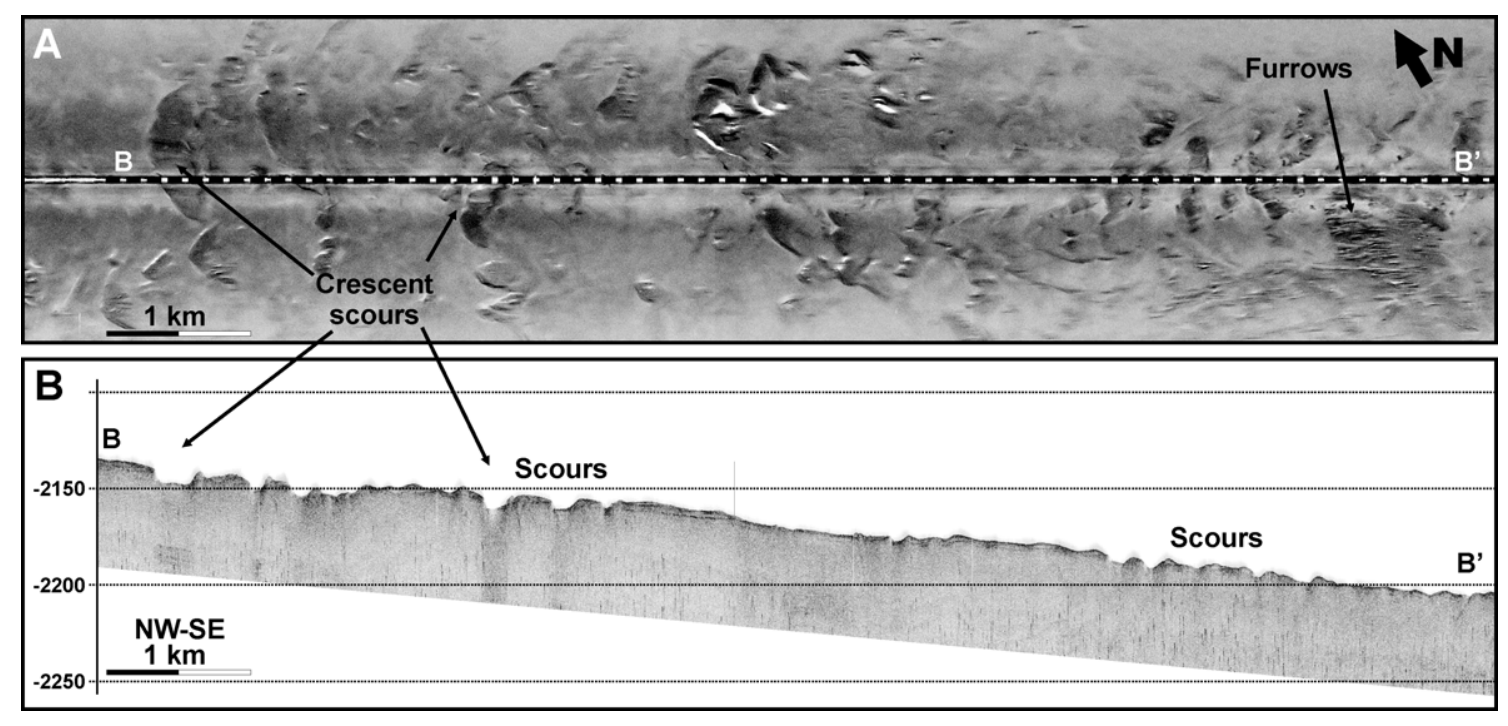

Fig. 10 


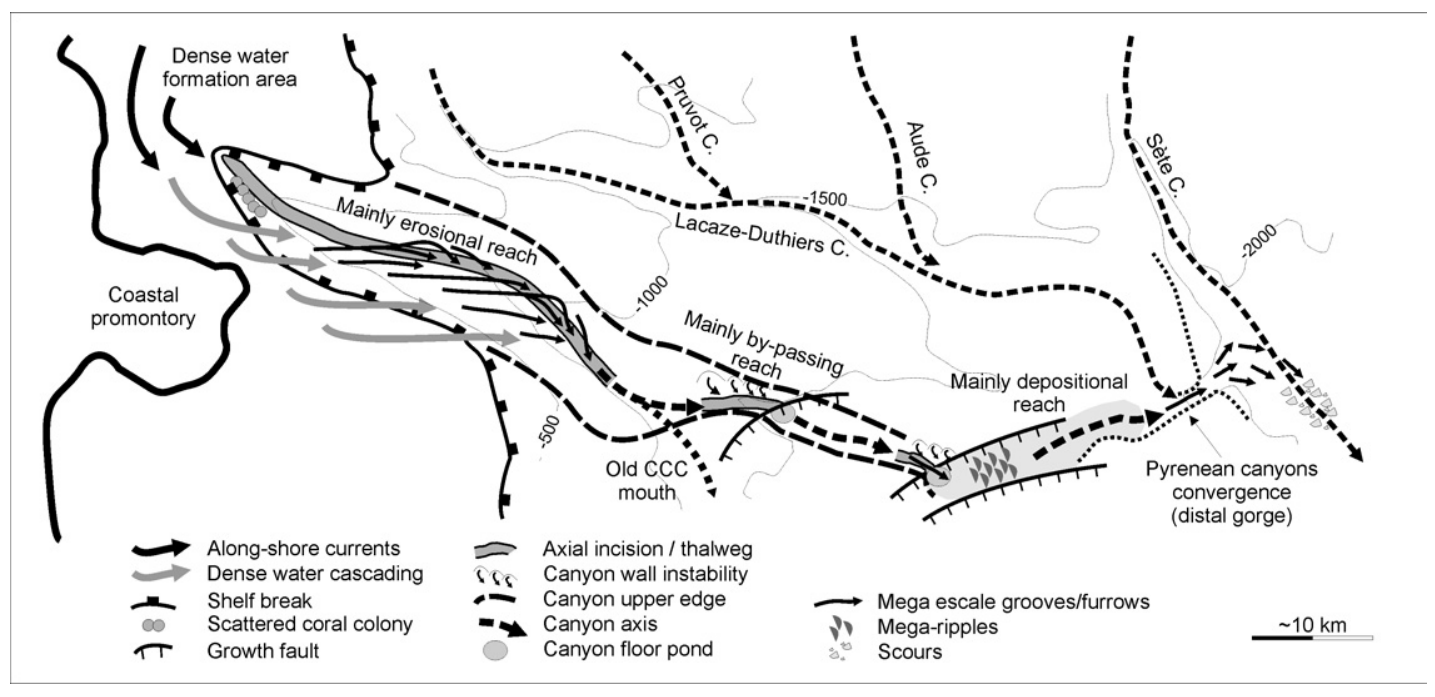

Fig. II 